\title{
Meningkatkan Kemampuan Manajemen Konflik Melalui Konseling Kelompok
}

\author{
Prahesti Khasanah \\ SMK Negeri 1 Seyegan \\ Jl. Kebingungan Km.8, Jamblangan, Margomulyo, Seyegan, Sleman, DI Yogyakarta, Indonesia \\ Email: prahestikhasanah@ymail.com
}

\begin{abstract}
This study aims to determine efetivitas group counseling in improving conflict management students. This type of research used in this research is action research in guidance and counseling (PTBK). The research was conducted at SMK Negeri 5 Yogyakarta. The research subjects are students of SMK Negeri 5 Yogyakarta class XI timber A amounting to 8 students. Tenik sampling using purposive sampling and data analysis techniques used to examine differences between the mean pretest and posttest after the action using t-test formula. The results of this research that there is an increase conflict management capacity at the student based on the pretest and posttest that shows that before the given action in the form of group counseling services in the medium category with the number 6 frequency by $75 \%$ and the high category with a number of second frequency by $25 \%$. Once given the actions that are in the high category with a number of frequency of 4 by $50 \%$ and very high category with a frequency of 4 by $50 \%$. Information from this research for teachers BK can be used as a basis for development of group counseling services to help increase conflict management capacity within each student. The results of this study may also be useful for parents, principals, deputy principal of student field, homeroom and subject teachers as information in an effort to improve students' ability of conflict management.
\end{abstract}

Keyword: conflict management, group counseling, action research in guidance and counseling

Penelitian ini bertujuan untuk mengetahui efetivitas konseling kelompok dalam meningkatkan manajemen konflik siswa. Jenis penelitian yang digunakan dalam penelitian ini adalah penelitian tindakan dalam bimbingan dan konseling (PTBK). Penelitian ini dilaksanakan di SMK Negeri 5 Yogyakarta. Subjek penelitian siswa kelas XI kayu A SMK N 5 Yogyakarta yang berjumlah 8 siswa. Pengambilan sampel menggunakan tenik purposive sampling dan teknik analisis data digunakan untuk menguji perbedaan rerata pretest dan posttest setelah dilakukan tindakan menggunakan rumus t-tes. Hasil dari penelitian ini yaitu terjadi peningkatan kemampuan manajemen konflik pada siswa berdasarkan hasil pretest dan posttest yang menunjukan bahwa sebelum diberi tindakan berupa layanan konseling kelompok pada kategori sedang dengan jumlah frekuensi 6 sebesar 75\% dan pada kategori tinggi dengan jumlah frekuensi 2 sebesar 25\%. Setelah diberi tindakan berada pada kategori tinggi dengan jumlah frekuensi 4 sebesar $50 \%$ dan kategori sangat tinggi dengan frekuensi 4 sebesar 50\%. Informasi dari hasil penelitian ini bagi guru BK dapat dijadikan sebagai dasar pengembangan layanan konseling kelompok untuk membantu meningkatkan kemampuan manajemen konflik dalam diri masing-masing siswa. Hasil penelitian ini juga dapat berguna bagi orangtua, kepala sekolah, Wakil kepala kesiswaan, wali kelas, dan guru mata pelajaran sebagai informasi dalam upaya meningkatkan kemampuan manajemen konflik siswa.

Kata kunci: manajemen konflik, konseling kelompok, penelitian tindakan bimbingan konseling

\section{Pendahuluan}

Pendidikan merupakan salah satu kebutuhan manusia. Melalui pendidikan diharapkan setiap individu mendapat kehidupan yang layak dimasa yang akan datang. Tanpa adanya pendidikan manusia akan sulit berkembang dan menyesuaikan diri dalam kehidupan dan menghadapi zaman yang semakin maju. Pendidikan merupakan usaha agar manusia dapat mengembangkan potensi yang ada pada diri individu tersebut melalui proses pembelajaran.

Pendidikan merupakan hak setiap insan seperti yang termuat dalam Undang-undang Dasar Negara Republik Indonesia tahun 1945 pasal 31 ayat (1) menyebutkan bahwa setiap warga negara berhak mendapat pendidikan, dan ayat (3) menegaskan bahwa pemerintah mengusahakan dan menyelenggarakan satu sistem pendidikan nasional yang meningkatkan keimanan dan ketaqwaan serta akhlak mulia dalam rangka 


\section{MANAJEMEN KONFLIK}

mencerdaskan kehidupan bangsa yang diatur dengan undang-undang. Pendidikan terbagi dalam dua jenis seting, yakni pendidikan formal dan pendidikan nonformal. Sekolah tidak akan berjalan tanpa adanya komponen-komponen yang mendukung komponen sekolah tersebut yang meliputi kurikulum dan proses belajar mengajar, administrasi dan manajemen sekolah, organisasi dan kelembagaan sekolah, sarana dan prasarana, ketenagaan, pembiayaan, peserta didik, peran serta masyarakat, lingkungan, dan kultur sekolah. Salah satu komponen sekolah adalah guru Bimbingan dan Konseling.

Menurut Permendiknas No.22/2006 tentang standar isi, pelayanan Bimbingan dan Konseling diletakan sebagai bagian dari kurikulum khususnya tentang materi pengembangan diri. Dalam hal ini peran guru bimbingan dan konseling di sekolah sangat diperlukan dalam mandampingi siswa. Idealnya setiap satu guru menangani 150 siswa agar lebih efektif dan mengetahui karakteristik dan masalah-masalah yang dialami oleh siswa. Oleh karena itu, perlu adanya pendekatan dengan melakukan bimbingan kelas sesuai dengan kebutuhan siswa, konseling individu, dan konseling kelompok.

Bimbingan dan konseling di sekolah memiliki peranan dalam membantu mengioptimalkan perkembangan siswa. Penerapan program bimbingan dan konseling di sekolah berupaya untuk memfasilitasi siswa agar mampu mengembangkan potensi dirinya atau mencapai tugas-tugas perkembangannya yang menyangkut aspek fisik, emosional, intelektual, sosial, dan moral spiritual. Melalui berbagai jenis layanan dalam bidang pribadi, belajar, sosial, dan karier, bimbingan dan konseling berupaya membentuk karakter siswa untuk dapat menjadi pribadi yang berbudi pekerti dan mandiri.

Siswa adalah seorang individu yang sedang berada dalam proses perkembangan yaitu berkembang ke arah kematangan atau kemandirian. Untuk mencapai kematangan , siswa memerlukan bimbingan karena mereka masih kurang memiliki pemahaman atau wawasan tentang diri, lingkungan, dan pengalaman dalam menentukan arah kehidupannya. Dalam proses perkembangannya tersebut, siswa tidak lepas dari konflik atau pertentangan.

Konflik yang dihadapi siswa dapat terjadi dalam berbagai tingkatan baik intrapersonal, interpersonal, intragroup, intraorganisasi, maupun interorganisasi. Konflik akan terjadi di sekolah sejalan dengan meningkatnya kompleksitas permasalahan yang terjadi di dalamnya. Konflik dapat terjadi pada siswa dengan siswa, tetapi tidak menutup kemungkinan antara siswa dengan guru, guru dengan guru, siswa dengan karyawan sekolah, karyawan sekolah dengan guru, kepala sekolah dengan guru atau karyawan, dan lain-lain. Konflik antara sekolah dan masyarakat di sekitarnya juga dapat terjadi.

Konflik pada siswa mempunyai pengaruh terhadap interaksi sosial siswa di sekolah dengan teman sebayanya. Konflik dapat muncul dengan ditandai perbedaan pendapat, perbedaan pola pikir, dan perbedaan karakter siswa yang bermacam-macam. Konflik seharusnya bisa membuat siswa disekolah dapat berfikir lebih kritis sebab jika dikelola dengan baik dapat dijadikan sebagai sember ide dan kreativitas yang dapat digunakan sebagai bahan perbaikan dan evaluasi yang lebih inovatif dan menghasilkan solusi yang sifatnya membangun.

Konflik yang terjadi di sekolah kerap menimbulkan dampak negatif jika tidak teratasi dengan managemen yang baik. Siswa di sekolah saling berinteraksi sosial dalam pergaulannya. Pergaulan tersebut tidak menutup kemungkinan terjadinya konflik. Sebagai contohya adalah fenomena konflik di sekolah yang terjadi di kota Jakarta. Konflik hingga tawuran yang terjadi pada siswa SMA Negeri 6 dan SMA Negeri 70 Jakarta menyebabkan salah seorang siswa SMA Negeri 6 kelas $\mathrm{X}$ berusia 15 tahun, meninggal akibat luka bacok pada bagian dada (Detikcom, 2012).

Hasil observasi peneliti di satu SMP swasta di Sleman pada tanggal 13 Agustus 2014 memperoleh hasil bahwa telah tejadi konflik antara guru dengan siswa dengan permasalahan mengenai sikap siswa yang tidak sopan terhadap guru mata pelajaran. Menurut Wahyudi (2011: 34) konflik yang terjadi antara guru dengan siswa berkenaan penegaan disiplin oleh guru, proses belajar yang kurang memuaskan siswa atau guru kurang memperhatikan siswa. Konflik guru dengan kepala sekolah menyangkut masalah pembagian tugas yang tidak merata, sistem ganjaran tidak berdasarkan prestasi kerja. Perbedaan pendapat antara wali murid karena terlalu banyak mencampuri kurikulum sekolah, 


\section{KHASANAH}

wali murid memandang guru tidak mampu meningkatkan prestasi belajar anaknya.

Beragam dan kompleksitas masalah di sekolah, guru bimbingan dan konseling dalam rangka memberikan layanan bimbingan dan konseling memiliki berbagai ragam jenis layanan dan kegiatan. Tugas guru bimbingan dan konseling salah satunya yaitu mendampingi siswa yang memiliki masalah dan membantu menyelesaikan dengan jalan konseling individu maupun konseling kelompok. Maka dari itu untuk mempersingkat waktu siswa yang memiliki masalah yang serupa dapat diselesaikan secara bersama dengan konseling kelompok agar mudah untuk menyelesaikannya, agar siswa tidak merasa sendiri dalam menghadapi masalah yang sedang dialami pada saat itu.

Konseling kelompok pada umumnya tidak saja berorientasi pada siswa yang memiliki masalah yang sama, namun siswa yang memiliki masalah yang beragam juga dapat dipecahkan melalui konseling kelompok dengan dipimpin oleh guru bimbingan dan konseling. Konseling kelompok merupakan suatu upaya remidial saat membahas topik yang menggangu atau menghambat proses belajar dan perkembangan kelompok siswa tertentu. Melalui pemecahan permasalahan secara bersama-sama akan membangun sikap tolong menolong dan saling menghargai.

Hasil penelitian yang dilakukan Widaryati (2013) menunjukkan bahwa layanan konseling kelompok efektif untuk meningkatkan self efficacy siswa SMA. Bandura dalam Widaryanti (2013) mengemukakan bahwa individu yang mempunyai efikasi diri yang rendah cenderung menyerah ketika dihadapkan pada suatu permasalahan. Saat individu menghadapi sebuah konflik membutuhkan sebuah sikap yang tidak mudah menyerah dalam memecahkan permasalahan yang memicu terjadinya konflik. Melalui kegiatan konseling kelompok, siswa belajar untuk membantu memecahkan permasalahan yang dialami oleh anggota kelompok melalui dinamika kelompok yang dipimpin oleh seorang konselor. Selain itu, siswa belajar untuk mendengarkan pendapat dari anggota kelompok yang tidak selalu sama dengan pendapatnya sendiri. Dengan demikian, konseling kelompok dipandang memiliki potensi untuk meningkatkan kemampuan management konflik siswa.

Fenomena di lapangan, guru Bimbingan dan Konseling yang biasanya membantu menyelesaikan konflik hanya dari luarnya dengan sekedar mempertemukan siswa yang berkonflik dengan berjabat tangan, dan menganggap masalah selesai melalui berjabat tangan. Kondisi demikian, masih ada kemungkinan di luar sekolah siswa dendam dan berkonflik kembali. Pada kenyataan di lapangan menunjukan fenomena yang cukup nampak terjadinya konflik. Hasil observasi yang dilakukan peneliti di salah satu sekolah swasta pada 13 Agustus 2014 di Sleman menunjukan bahwa masih rendahnya manajemen konflik pada siswa, karena masih banyak terjadi konflik di dalam sekolah. Selama observasi yang peneliti lakukan banyak konflik yang terjadi diantaranya konflik antar geng, rebutan pacar atau gebetan, dan dibenci teman satu kelas.

Dececco dan Richards telah mengkaji penggunaan tindak kekerasan oleh remaja dalam menyelesaikan konflik di Amerika Serikat (Johnson, Johnson, Dudley \& Acikgos, 1994). Menurutnya sebanyak 90\% konflik yang dialami remaja tidak terselesaikan, dan 25\% remaja menyelesaikannya dengan cara paksaan, kekerasan, atau perkelahian. Persentase penggunaan kekerasan oleh remaja di Indonesia tidak sebesar hasil penelitian di Amerika tersebut. Mengacu pada penelitian yang dilakukan Aryanto (1992) bahwa remaja di Jakarta yang melakukan tindak kekerasan dalam menyelesaikan masalahnya sekitar 3.8\%.

Secara psikologi siswa kelas XI SMK tergolong masa remaja, masa remaja yaitu masa yang belum stabil dan masih banyak konflik yang terjadi dalam dunia remaja yang belum bisa mereka atasi. Pada umumnya tidak sedikit para remaja yang berkonflik entah itu konflik yang berasal dari dalam maupun luar. Konflik yang berkepanjangan pada remaja tersebut jika dibiarkan saja akan menggangu perkembangan remaja, menghambat tugas-tugas perkembangan yang seharusnya dicapai remaja pada usia tersebut, tetapi jika hal tersebut dibiarkan begitu saja tanpa adanya penangan maka konflik-konflik dalam diri remaja itu akan lebih meluas dan berkepanjangan 
Berdasarkan pemaparan di atas bahwa pada umumnya siswa belum memperoleh layanan bimbingan secara optimal. Hal ini disebabkan karena terbatasnya jam bimbingan dan konseling di sekolah bagi siswa, dan guru bimbingan dan konseling lebih sering melakukan bimbingan secara klasikal dengan metode yang kurang efektif dibandingkan melakukan layanan konseling kelompok atau konseling individu. Sehingga siswa belum dapat sepenuhnya memanfaatkan layanan bimbingan dan konseling sebagai tempat untuk mengembangkan diri dan sebagai upaya membantu pemecahan masalah yang dihadapai siswa sebab siswa masih menganggap paradigma guru bimbingan dan konseling itu sebagai polisi sekolah.

Melihat banyak dan rumitnya konflik yang terjadi di sekolah maka perlu adanya pembinaan manajemen konflik secara benar. Salah satu cara yang dapat dilakukan oleh guru bimbingan dan konseling adalah memberikan layanan konseling kelompok agar siswa dapat meningkatkan manajemen konflik. Berdasarkan fenomena di atas, peneliti ingin menggunakan layanan konseling kelompok untuk meningkatkan kemampuan siswa dalam melakukan manajemen konflik.

Penelitian ini bertujuan untuk mengetahui apakah melalui layanan konseling kelompok dapat meningkatkan manajemen konflik. Alasan peneliti menggunakan konseling kelompok untuk meningkatkan manajemen konflik karena konseling kelompok di sekolah bukan sekedar pemberian nasehat dari guru bimbingan dan konseling tetapi dalam memecahkan masalah, sebab ciri utama dari proses konseling yaitu pemecahan masalah itu berasal dari kesadaran dari siswa itu sendiri. Informasi dari hasil penelitian ini bagi guru BK dapat dijadikan sebagai dasar pengembangan layanan konseling kelompok untuk membantu meningkatkan kemampuan manajemen konflik dalam diri masing-masing siswa. Hasil penelitian ini juga dapat berguna bagi orangtua, kepala sekolah, Waka kesiswaan, wali kelas, dan guru mata pelajaran sebagai informasi dalam upaya meningkatkan kemampuan manajemen konflik siswa.

\section{Kajian Literatur}

\section{Manajemen Konflik}

Konflik merupakan salah satu esensi dalam kehidupan dan perkembangan manusia yang mempunyai karakteristik yang beragam. Manusia memiliki perbedaan jenis kelamin, strata sosial dan ekonomi, sistem hukum, bangsa, suku, agama, kepercayaan, aliran politik serta budaya dan tujuan hidupnya. Perbedaan inilah yang menimbulkan konflik. Selama masih ada perbedaan tersebut konflik tidak dapat dihindarkan dan selalu akan terjadi. Menurut Webster (dalam Pruitt dan Rubin, 2009: 9) mengemukakan bahwa istilah "conflict” didalam bahasa aslinya berarti suatu perkelahian, peperangan, atau perjuangan yaitu berupa konfrontasi fisik antara beberapa pihak. Kemudian istilah tersebut berkembang sampai pada aspek psikologis dibalik konfrontasi yang terjadi selain konfrontasi fisik itu sendiri. Definisi konflik menurut Webster yang kedua dalam (Pruitt dan Rubin, 2009:9) mengemukakan bahwa konflik berarti persepsi mengenai perbedaan kepentingan (perceived divergence of interest) atau suatu kepercayaan bahwa aspirasi pihakpihak yang berkonflik tidak dapat dicapai secara simultan.

Konflik sangat erat dalam kehidupan manusia. Hendricks (2006: 1) berpendapat bahwa konflik adalah sesuatu yang tak terhindarkan. Manusia selalu berjuang melawan konflik yang terjadi pada masa lampau yang cukup menyisakan pengaruh terhadap kehidupan. Aldag, R. J dan Stearns, T. M (dalam Wahyudi, 2011: 18) mengartikan konflik adalah ketidak sepahaman antara dua atau lebih individu atau kelompok sebagai akibat dari usaha kelompok lainnya yang mengganggu pencapaian tujuan. Dengan kata lain konflik timbul karena satu pihak mencoba untuk menghalangi atau menggangu pihak lain dalam usahanya mencapai suatu tujuan.

Berdasarkan beberapa teori di atas sesuai dengan judul penelitian dapat disimpulkan bahwa konflik adalah pertentangan atau konfrontasi antara siswa dengan sekelompok siswa mengenai perbedaan kepentingan akibat saling menghalangi dalam pencapaian tujuan sehingga antara kedua belah pihak terlibat konflik jika tidak dikelola atau dimanajemen dengan baik dan benar. Cummings (dalam Wahyudi, 2011: 47) 


\section{KHASANAH}

menyatakan bahwa "konflik antar orang di dalam organisasi tidak dapat diremehkan tetapi hal tersebut dapat dimanfaatkan ke arah produktif bila dikelola dengan baik”.

Criblin (dalam Wahyudi, 2011: 47) mengartikan "manajemen konflik merupakan teknik yang dilakukan pemimpin organisasi untuk mengatur konflik dengan cara menentukan peraturan dasar dalam bersaing”. Selanjutnya Wirawan (2013: 129) mendefinisikan "manajemen konflik sebagai suatu proses pihak yang terlibat konflik atau pihak ketiga menyusun strategi konflik dan menerapkannya untuk mengendalikan konflik agar menghasilakan resolusi yang diinginkan”. Pendapat senada oleh Wirawan (2013: 130) bahwa "menajemen konflik merupakan aktivitas untuk mengendalikan dan mengubah konflik demi menciptakan keluaran konflik yang menguntungkan. Manajemen konflik merupakan upaya untuk mengarahkan konflik destruktif menjadi konflik konstruktif sehingga akan menimbulkan dan mengembangkan kreativitas dan inovasi”. Berdasarkan definisi konflik dari beberapa tokoh di atas sesuai dengan judup penelitian dapat disimpulkan bahwa Manajemen konflik yaitu upaya untuk mengendalikan dan mengubah konflik destruktif menjadi konflik konstruktif sehingga dapat menghasilkan resolusi yang diinginkan bagi siswa sehingga konflik yang terjadi atar siswa tidak selalu diasumsikan sebagai sesuatu yang negatif.

Gaya konflik dapat membantu seseorang untuk menentukan alternatif cara dalam menyelesaikan masalah. Jika gaya konflik dapat diidentifikasikan maka akan meningkatkan pemahaman dan motivasi orang lain selama berkonflik. Berikut lima gaya konflik menurut Hendricks (2006: 48). 1) gaya mempersatukan; 2) gaya kerelaan membantu; 3) gaya mendominasi; 4) gaya menghindar dan 5) gaya kompromi.

Gaya mempersatukan adalah salah satu gaya konflik. Individu yang memilih gaya ini saling melakukan tukar menukar informasi. Kemudian ada keinginan untuk mengamati perbedaan dan mencari solusi yang dapat diterima oleh semua kelompok. Penyelesaian konflik dengan gaya ini dapat mendorong tumbuhnya creative thinking (berfikir kreatif), mengembangkan alternatif, dan dapat menekankan diri sendiri dan orang lain dalam mensitetiskan informasi dari perspektif yang berbeda.
Gaya kerelaan untuk membantu adalah gaya yang dapat membantu menempatkan nilai yang tinggi untuk orang lain sementara dirinya sendiri dinilai rendah. Gaya ini mungkin mencerminkan rendahnya penghargaan terhadap diri sendiri oleh individu yang bersangkutan. Strategi rela membantu berperan dalam menyempitkan perbedaan antara kelompok dan mendorong untuk mencari kesamaan dasar. Gaya ini dengan tidak disadari dengan cepat dapat membuat orang rela untuk mengalah.

Gaya mendominasi yaitu gaya yang lebih menekankan pada diri sendiri. Gaya mendominasi ini meremehkan kepentingan orang lain. Gaya ini adalah strategi yang efektif bila suatu keputusan yang cepat dibutuhkan. Gaya ini terlihat dengan adanya penyerangan untuk menang. Gaya mendominasi sangat membantu jika kurannya pengetahuan tentang isu yang menjadi faktor munculnya konflik.

Gaya menghindar adalah gaya yang menghindar dari persoalan diantaranya menghindar dari tanggung jawab. Penggunaan gaya penyelesaian konflik menghindar cukup dirasa efektif bila memang dibutuhkan dalam waktu tertentu. Gaya kompromi adalah gaya yang perhatian pada diri sendiri maupun pada orang lain yang berada pada tingkatan sedang. Kompromi akan efektif bila masalah yang dihadapi cukup kompleks. Kompromi bisa menjadi pemecah perbedaan. Kompromi hampir selalu dijadikan sarana oleh semua kelompok yang berselisih untuk memberikan sesuatu untuk mendapatkan jalan keluar atau pemecah.

Berdasarkan pemaparan di atas sesuai dengan judul penelitian dapat disimpulkann bahwa gaya manajemen konflik itu ada lima yang masingmasing memiliki arti yang berbeda. Maka dari itu siswa diharapkan untuk memahaminya sehingga jika mereka mengalami konflik dapat mengetahui gaya manajemen konflik yang cocok terhadap konflik yang dialami pada masing-masing siswa yang berkonflik.

Tujuan manajemen konflik menurut Wirawan (2013: 132) adalah sebagai berikut: 1) memfokuskan diri pada visi misi konflik dapat menggangu perhatian serta energi dan kemampuan anggota organisasi untuk mencapai visi, misi, dan tujuan yang strategis. Jika tidak dapat dimanajemeni dengan baik konflik akan berkembang. Oleh karena itu agar visi misi 


\section{MANAJEMEN KONFLIK}

berjalan sesuai harapan dan tujuan maka harus dapat memfokuskan diri pada konflik bukan pada pencapaian visi, misi, dan tujuan; 2) memahami orang lain dan keberagaman, dalam interaksi sosialnya manusia itu saling berkomunikasi namun antara satu individu dengan individu yang lain memiliki keragaman karakteristik. Individu harus memahami perbedaan suku, agama, ras, bahasa pribadi, perilaku, pola pikir, dan sebagainnya. Manajemen konflik diarahkan agar pihak-pihak yang terlibat konflik memahami keragaman tersebut; 3) meningkatkan kreativitas, Sy. Landau, Barbara Landau, dan Daryi Landau (dalam Wirawan, 2013: 132) konflik jika dimanajemeni akan menciptakan kreativitas dan inovasi, serta mengembangkan kreativitas pada pihak-pihak yang terlibat konflik; 4) meningkatkan keputusan, suatu keputusan yang baik atau bijak merupakan keputusan yang bertumpu pada berbagai alternatif yang didukung oleh informasi yang akurat untuk memilih salah satu alternatif yang terbaik.

Berdasarkan pemaparan di atas sesuai dengan judul penelitian tujuan manajemen konflik yaitu agar siswa saling memahami perbedaan yang menyebabkan terjadinya konflik sehingga siswa dapat segera mengelola konflik tersebut menjadi konflik yang sifatnya membangun. Konflik tidak hanya harus diterima dan dikelola dengan baik tetapi harus didorong karena konflik merupakan kekuatan untuk mendatangkan perubahan dan kemajuan dalam lembaga. Edelman,R. J. (dalam Wahyudi, 2011: 47) menegaskan bahwa jika konflik dikelola secara sistematis dapat berdampak positif yaitu memperkuat hubungan kerjasama, meningkatkan kepercayaan dan harga diri, mempertinggi kreativitas dan produktivitas. Tidak ada teknik pengendalian konflik yang dapat digunakan dalam segala situasi karena setiap pendekatan mempunyai kelebihan dan kekurangan.

Winardi (dalam Wahyudi, 2011: 49) berpendapat bahwa manajemen konflik meliputi kegiatan-kegiatan: 1) menstimulasi konflik; 2) mengurangi atau menekan konflik, dan 3) menyelesaikan konflik. Konflik yang dikelola secara positif dan konstruktif akan dapat mencapai tujuan. Dengan pendekatan dalam pengelolaan konflik menjadi suatu hal yang penting. Leavitt, H. J. (dalam Wahyudi, 2011: 57) mengemukakan bahwa untuk mengatasi konflik dapat dilakukan pendekatan sebagai berikut: 1) konfrontasi adalah pemecahan masalah untuk mengurangi ketegangan melalui pertemuan tatap muka antar kelompok yang sedang berkonflik. Tujuan pertemuan adalah untuk mengenal permasalahan dan menyelesaikannya. Kelompokkelompok yang sedang berkonflik diberi kesempatan untuk berdebat secara terbuka mengenai berbagai topik dan membahas semua masalah yang relevan sampai keputusan tercapai.; 2) teknik negosiasi dan tawar menawar adalah perundingan mempertemukan dua pihak dengan kepentingan yang berbeda untuk mencapai sebuah persetujuan. Masing-masing pihak membawa serangkaian usulan yang kemudian didiskusikan dan dilaksanakan. Setiap anggota menyadari pentingnya tawar menawar untuk menyelesaikan perdebatan, masing-masing menurunkan tuntutannya sehingga mencapai titik temu. Dalam perundingan tidak ada yang dikalahkan semua pihak mengindarkan perasaan telah memenangkan tuntutan; 3) penyerapan adalah cara mengelola konflikorganisasi antara kelompok besar dengan kelompok kecil. Kelompok kecil mendapatkan sebagian yang diinginkannya tetapi sebagai konsekuensinya harus bertanggung jawab terhadap pelaksanaannya.

Berdasarkan pemaparan di atas dihubungkan dengan judul penelitian bahwa pendekatan manajemen konflik merupakan upaya yang diberikan kepada siswa agar mereka mampu menerapkan cara-cara mengelola konflik yang mereka hadapi secara benar, agar konflik yang mereka hadapi tidak berkepanjangan dan dapat teratasi secara tepat.

\section{Remaja}

Menurut Ali, remaja dalam bahasa aslinya disebut adolescence yang berasal dari bahasa latin adolesecere yang artinya tumbuh atau tumbuh untuk mencapai kematangan. Bangsa primitif dan orang-orang purbakala memandang masa puber dan masa remaja tidak berbeda dengan periode lain dalam rentang kehidupan. Anak dianggap sudah dewasa apabila sudah mampu mengadakan reproduksi. Siswa kelas XI SMK termasuk pada masa remaja awal dalam hal ini siswa masih cukup labil dalam berfikir dan bertindak oleh karena itu mereka sangat rentan terhadap konflik. 


\section{KHASANAH}

Ada tujuh ciri-ciri remaja yang dapat menimbulkan konflik bagi siswa sehingga perlu manajemen konflik untuk mengatasinya agar remaja terhindar dari konflik. Siswa kelas XI SMK yang sudah memasuki masa remaja awal agar siswa dapat mencapai kemandiriaan emosional sehingga mereka lebih terarah dan dalam pencapain tugas perkembangan tersebut mereka dapat memanajemen konflik yang dihadapi. Masa remaja seringkali dikenal dengan masa mencari jati diri sebab remaja merupakan masa peralihan antar masa anak-anak dan masa kehidupan orang dewasa. Menurut Ali dan Asrori (2009: 16) remaja memiliki beberapa karakteristik diantaranya yaitu kegelisahan, pertentangan, mengkhayal, aktivitas bekelompok, dan keinginan mencoba segala sesuatu.

Pada masa remaja banyak angan-angan dan keinginan yang besar dalam mewujudkan masa depan akan tetapi angan-angan dan keinginan jauh lebih besar dibandingkan dengan kemampuannya. Remaja disatu pihak mereka ingin mendapat pengalaman sebanyak-banyaknya untuk menambah pengetahuan tetapi dipihak lain mereka merasa belum mampu melakukan berbagai hal dengan baik sehingga tidak berani mengambil tindakan mencari pengalaman langsung dari sumbernya. Tari-menari antara angan-angan yang tinggi dengan kemampuannya yang belum dapat tercapai mengakobatkan mereka diliputi perasaan gelisah.

Sebagai individu yang sedang mencari jati diri remaja berada dalam situasi psikologis antara ingin melepaskan diri dari orang tua dan perasaan masih belum mampu untuk mendiri. Akan tetapi pada umumnya remaja sering mengalami kebingungan karena sering terjadi pertentangan pendapat antara mereka dengan orang tua. Pertentangan yang sering kali terjadi itu menimbulkan keinginan remaja untuk melepaskan diri dari orang tua kemudian ditentangnya sendiri karena dalam diri remaja ada keinginan untuk memperoleh rasa aman. Remaja sebenarnya belum begitu berani mengambil resiko dari meninggalkan lingkungan keluarganya yang jelas aman bagi dirinya. Keinginan melepaskan diri itu belum disertai dengan kesanggupan untuk berdiri sendiri tanpa bantua orang tua dalam soal keuangan, akibatnya pertentangan yang sering terjadi itu akan menimbulkan kebingungan dalam diri remaja.
Keinginannya untuk menjelajah dan bertualang tidak semuanya tersalurkan. Biasanya terhambat dari segi keuangan atau biaya. Sebab menjelajahi lingkungan sekitar yang luas akan membutuhkan biaya banyak akan tetapi kebayakan remaja hanya memperoleh uang dari pemberian orang tuannya. Akibatnya mereka berkhayal, mecari kepuasan, bahkan meyalurkan khayalannya melalui dunia fantasi. Khayalan remaja putra biasanya berkisar soal prestasi dan jenjang karier sedangkan remaja putri lebih mengkhayalkan romantika hidup. Khayalan ini tidak selamanya bersifat negatif, sebab khayalan tersebut kadang-kadang menghasilkan sesuatu yang sifatnya konstruktif.

Berbagai macam kegiatan remaja seringkali tidak dapat terpenuhi karena bermacam-macam kendala, yang sering terjadi adalah tidak tersedianya biaya. Adanya macam-macam larangan dari orang tua seringkali melemahkan atau bahkan mematahkan semangat remaja. Kebanyakan remaja menemukan jalan keluar dari kesulitan setelah mereka berkumpul dengan rekan sebaya untuk melakukan kegiatan bersama. Mereka melakukan kegiatan berkelompok sehingga berbagai kendala dapat di atasi bersamasama.

Pada umumnya remaja memiliki rasa ingin tahu yang tinggi. Karena didorong oleh rasa ingin tahu yang tinggi remaja cenderung ingin bertualang, menjelajah segala sesuatu, dan mencoba segala sesuatu yang belum pernah dialaminya. Selain itu didorong olehg keinginan seperti orang dewasa menyebabkan remaja ingin mencoba melakukan apa yang sering dilakukan orang dewasa. Akibatnya tidak jarang secara sembunyi-sembunyi remaja pria mencoba merokok. Remaja putri seringkali mencoba memakai kosmetik baru meskipun peraturan sekolah tidak memperbolehkan. Seolah-olah dalam hati kecil remaja berkata bahwa mereka ingin membuktikan kalau sebenarnya dirinya mampu berbuat seperti yang dilakukan orang dewasa.

Berdasarkan pemaparan di atas disesuaikan dengan judul penelitian bahwa lima karateristik remaja di atas sangat mempengaruhi timbulnya konflik pada diri remaja sebab pada masa ini remaja berada pada masa pencarian jati diri. Oleh karena itu karakteristik remaja sangat berpengaruh pada timbulnya konflik yang dialami 


\section{MANAJEMEN KONFLIK}

oleh siswa SMK yang sudah berada pada usia remaja awal dan dengan layanan konseling kelompok diharapkan siswa memperoleh pemberian informasi dan pemecahan hambatan siswa dalam menyelesaikan konflik dapat terselesaikan.

\section{Tugas Perkembangan Masa Remaja}

Tugas perkembangan remaja difokuskan pada upaya meninggalkan sikap dan perilaku kekanakkanakan serta berusaha untuk mencapai kemampuan bersikap dan berperilaku secara dewasa. Menurut Hurlock (dalam Ali, 2009: 10) meyatakan bahwa tugas perkembangan masa remaja adalah berusaha mampu menerima keadaan fisiknya, mampu menerima dan memahami peran seks usia dewasa, mampu membina hubungan baik dengan anggota kelompok yang berlainan jenis, mencapai kemandirian emosioanal, mencapai kemandirian ekonomi, mengembangkan konsep ketrampilan intelektual yang sangat diperlukan untuk melakukan peran sebagai anggota masyarakat, memahami dan menginternalisasikan nilai-nilai orang dewasa dan orang tua, mengembangkan perilaku tanggung jawab sosial yang diperlukan untuk memasuki dunia dewasa, mempersiapkan diri untuk memasuki perkawinan, dan memahami dan mempersiapkan berbagai tanggung jawab kehidupan keluarga.

Berdasarkan pemaparan di atas sesuai dengan judul penelitian bahwa tugas perkembagan remaja perlu diketahui khususnya pada siswa kelas XI SMK yang sudah memasuki masa remaja awal agar siswa dapat mencapai kemandiriaan emosional sehingga mereka lebih terarah dan dalam pencapain tugas perkembangan tersebut mereka dapat memanajemen konflik yang dihadapai.

\section{Konseling Kelompak}

Jenis layanan yang diberikan dalam penelitian ini yaitu dengan jenis layanan responsif konseling kelompok guna mengintervensi konflik siswa yang muncul segera dan dirasakan pada saat itu juga. Yusuf (2009: 83) menyatakan bahwa konseling kelompok adalah proses konseling yang dilaksanakan untuk membantu siswa memecahkan masalahnya melalui kelompok. Dalam konseling kelompok ini masing-masing siswa mengemukakan masalah yang dialaminya kemudian satu sama lain saling memberikan masukan atau pendapat untuk memecahkan masalah tersebut.

Berdasarkan beberapa teori di atas maka kaitannya dengan penelitian ini, cukup jelas bahwa pengertian konseling kelompok adalah upaya bantuan dari orang yang kompeten kepada sekelompok individu dalam rangka memberikan kemudahan dalam menyelesaikan permasalahan yang dihadapi siswa. Dalam penelitian ini tujuan konseling kelompok adalah mengajarkan siswa agar dapat terbuka dalam mengungkapkan masalah, serta saling menghargai perbedaan yang dapat memicu timbulnya konflik dan saling pengertian satu sama lain.

Manfaat konseling kelompok bagi siswa yaitu untuk proses diskusi menyamakan pendapat atas perbedaan yang menimbulkan konflik agar tidak bekepanjangan dan menggangu siswa dalam proses interaksi sosial serta proses belajarnya di sekolah. Tahap-tahap dalam pelaksanaan konseling kelompok sangat penting yaitu sebagai pengatur alokasi waktu dan kontrol terhadap tindakan-tindakan yang perlu dilakukan sebagai monitoring dan evaluasi pada saat proses konseling kelompok berlangsung. Menurut Natawidjaja (2009: 117) pada umumnya tahaptahap konseling terdiri atas tiga tahap yaitu: 1) tahap awal; 2) tahap pertengahan; dan 3) tahap akhir.

\section{Kaitan Layanan Konseling Kelompok dengan Manajemen Konflik}

Layanan konseling kelompok merupakan layanan dalam bimbingan dan konseling yang dilaksanakan untuk membantu siswa memecahkan masalahnya melalui kelompok. Dalam konseling kelompok ini masing-masing siswa mengemukakan masalah yang dialaminya kemudian satu sama lain saling memberikan masukan atau pendapat untuk memecahkan masalah tersebut. Dalam proses konseling kelompok menggunakan dinamika kelompok untuk mempermudah dalam menjalankan konseling kelompok guna untuk menciptakan suasana keterbukaan, keakraban, saling menghargai dan berbagi rasa antar anggota kelompok. Suasana dalam konseling kelompok akan memudahkan siswa untuk saling berinteraksi dengan anggota kelompok dan meningkatkan kerja sama satu sama lain untuk memenuhi 


\section{KHASANAH}

kebutuhan bersama dalam memecahkan suatu masalah yang dihadapi bersama melalui bertukar pendapat dalam diskusi.

Menurut Winkel dan Hastuti (2006: 547) dinamika kelompok yaitu studi tentang kekuatankekuatan sosial dalam suatu kelompok yang memperlancar dan menghambat proses kerja sama dalam kelompok, segala metode, sarana, dan teknik yang dapat diterapkan bila sejumlah orang bekerja sama dalam kelompok. Pendapat di atas menjelaskan bahwa dinamika kelompok dalam proses layanan konseling kelompok sangat diperlukan guna melatih individu untuk saling berinteraksi sosial antar anggota kelompok. Layanan konseling kelompok dalam hal ini berkaitan dengan bagaimana siswa dapat memanajemeni konflik yang mereka hadapi karena dalam konseling kelompok seseorang yang terlibat dalam interaksi kelompok tersebut memiliki kesadaran untuk memanajemen konflik yang terjadi ketika proses diskusi berlangsung, munculnya suatu perbedaan, silang pendapat, dan pertentangan antar anggota kelompok mereka mampu mengelola konflik tersebut.

\section{Metode Penelitian}

Jenis penelitian yang digunakan oleh peneliti dalam penelitian ini adalah penelitian tindakan dalam bimbingan dan konseling (PTBK). Penelitian ini dilaksanakan di SMK N 5 Yogyakarta yang beralamatkan di Jl. Kenari No.71 Rt 21 Rw 07 Muja Muju Umbulharjo Yogyakarta. Waktu penelitian ini dilaksanakan pada semester ganjil tahun ajaran 2014/2015. Subjek dan sasaran dalam penelitian ini siswa kelas XI kayu A SMK N 5 Yogyakarta TA 2014/2015 yang berjumlah 8 siswa. Pengambilan sampel menggunakan tenik purposive sampling dengan pertimbangan pada hasil wawancara yang diberikan kepada guru bimbingan dan konseling, wali kelas, dan ketua kelas yang kemudian diperkuat dengan hasil angket tentang manajemen konflik. Instrumen yang digunakan dalam penelitian ini adalah pedoman observasi dan angket. Angket dilaksanakan dalam rangka untuk mengetahui apakah dengan layanan konseling kelompok dapat meningkatkan manajemen konflik khususnya pada siswa kelas XI kayu A
SMK N 5 Yogyakarta. Teknik analisis data digunakan untuk menguji perbedaan rerata pretest dan posttest setelah dilakukan tindakan menggunakan rumus $t$-tes.

\section{Hasil Penelitian Dan Pembahasan}

Skor angket kemampuan manajemen konflik pre test dan post test dianalisis menggunakan bantuan komputer progam SPSS (statistical Package for Social Sciens) untuk melihat peningkatan pemahaman siswa mengenai Kemampuan manajemen konflik melalui layanan konseling kelompok. Berdasarkan hasil analisis diperoleh deskripsi data variabel Kemampuan manajemen konflik siswa dapat dilihat pada Tabel

Kecenderungan kemampuan manajemen konflik siswa sebelum diberi tindakan berada pada kategori sedang. Dalam penelitian ini juga menggunakan lembar observasi untuk mengamati aktivitas dan respon siswa selama mengikuti layanan konseling kelompok terkait peningkatan kemampuan manajemen konflik. Berikut ini adalah gambar 1 skor hasil observasi pelaksanaan layanan konseling kelompok.

Tabel 1

Deskripsi Data Variabel Kemampuan Manajemen Konflik

\begin{tabular}{ccccc}
\hline No & Nama & $\begin{array}{c}\text { Skor } \\
\text { sebelum } \\
\text { tindakan } \\
\text { (pretest) }\end{array}$ & $\begin{array}{c}\text { Skor } \\
\text { setelah } \\
\text { tindakan } \\
\text { (posttest) }\end{array}$ & $\begin{array}{c}\text { Gain Skor } \\
\text { (d) }\end{array}$ \\
\hline 1 & TT & 112 & 143 & 31 \\
2 & AK & 113 & 138 & 25 \\
3 & GT & 108 & 136 & 28 \\
4 & RL & 111 & 135 & 24 \\
5 & AD & 117 & 140 & 23 \\
6 & IM & 106 & 130 & 24 \\
7 & DS & 107 & 134 & 27 \\
8 & YG & 119 & 140 & 21 \\
\multicolumn{7}{c}{ Jumlah } & 893 & 1096 & 203 \\
\multicolumn{7}{c}{ Mean } & 111.62 & 137.00 & 25.38 \\
\hline \multicolumn{5}{c}{} \\
\end{tabular}

Hasil pelaksanaan layanan konseling kelompok dari pertemuan 1 sampai pertemuan ke 6 sebagaimana yang ditunjukkan pada Gambar 1, dapat dilihat bahwa ada kenaikan yang menunjukkan adanya peningkatan skor kualitas siswa dalam mengikuti layanan konseling 


\section{MANAJEMEN KONFLIK}

kelompok. Dari hasil observasi dapat dilihat bahwa ada peningkatan aktivitas dalam mengikuti layanan konseling kelompok dalam setiap pertemuan. Siswa antusias dan menyatakan menjadi lebih memahami arti pentingnya kemampuan manajemen konflik untuk menghadapi suatu permasalahan.

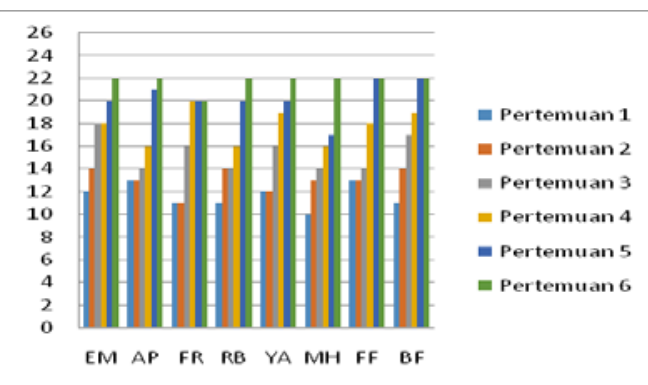

Gambar 1.

Hasil Observasi Pelaksanaan Layanan Konseling Kelompok

Untuk membuktikan perihal hasil penelitian, maka dilakukan uji hipotesis. Pengujian hipotesis yang diajukan dalam penelitian adalah layanan konseling kelompok mampu meningkatkan kemampuan manajemen konflik pada siswa kelas XI Kayu A SMK Negeri 5 Yogyakarta Tahun Ajaran 2014/2015. Pengujian hipotesis tersebut menggunakan bantuan komputer dengan progam SPSS untuk mengetahui koefisien t hitung sebesar 11.559 selanjutnya diadakan pengujian terhadap tabel nilai-nilai distribusi t dengan taraf 5\% untuk (n-1) 8-1=7 adalah 1.895. Hal ini menunjukkan bahwa nilai t hitung lebih besar dari t tabel yaitu $11.559>1.895$ atau $p=0.000(p<0.05)$. Berarti ada perbedaan yang signifikan antara peningkatan kemampuan manajemen konflik siswa sebelum dan setelah diberi layanan konseling kelompok. Setelah dicermati lebih lanjut terhadap peningkatan kemampuan manajemen konflik siswa diperoleh rerata sebelum diberi tindakan layanan konseling kelompok adalah 111.62 dan rerata setelah diberi layanan konseling kelompok adalah 137.00.

Dengan demikian maka hipotesis nihil (Ho) yang diajukan berbunyi "tidak ada peningkatan kemampuan manajemen konflik siswa melalui layanan konseling kelompok pada siswa kelas XI Kayu A SMK Negeri 5 Yogyakarta Tahun Ajaran 2014/2015” Ditolak. Sedangkan hipotesis alternatif (Ha) yang diajukan “ Ada peningkatan kemampuan manajemen konflik siswa melalui layanan konseling kelompok pada pada siswa kelas XI Kayu A SMK N 5 Yogyakarta Tahun Ajaran 2014/2015” Diterima sehingga teruji kebenarannya.

Hasil analisis data menunjukkan bahwa "ada peningkatan manajemen konflik melalui konseling kelompk pada siswa kelas XI Kayu A SMK N 5 Yogyakarta tahun ajaran 2014/2015”. Meningkatkan manajemen konflik tersebut dapat diketahui dari hasil observasi dan pemberian angket pre test dan post test. Data yang didapat dari hasi pre test dan post test menunjukan bahwa sebelum diberi tindakan berupa layanan layanan konseling kelompok pada kategori sedang dengan jumlah frekuensi 6 sebesar 75\% dan pada kategori tinggi dengan jumlah frekuensi 2 sebesar 25\%. Setelah diberi tindakan berada pada kategori tinggi dengan jumlah frekuensi 4 sebesar 50\% dan kategori sangat tinggi dengan frekuensi 4 sebesar 50\%.

Meningkatnya manajemen konflik berdasarkan hasil observasi diketahui pada hasil observasi bahwa ada respon dan aktivitas siswa pada setiap siklus tindakan. Pada siklus I siswa terlihat cukup antusias dalam mengikuti layanan konseling kelompok, dalam mengikuti proses konseling sesekali bercanda. Masih ragu-ragu dalam menyampaikan pendapat, jarang mengeluarkan pendapat, terkadang masih ada yang bertanya mengenai arahan yang diberikan oleh peneliti, ragu-ragu dalam mengungkapkan gagasannya, mau mengungkapkan pendapat jika ditunjuk, kadang-kadang masih ada siswa yang berbicara sendiri dengan temannya diluar tema yang ditentukanada siklus II siswa antusias mengikuti proses konseling kelompok dapat dilihat siswa bersemangat, datang tepat waktu sesuai janji. Siswa mengikuti arahan yang diberikan oleh peneliti mengenai aturan-aturan dalam proses konseling kelompok dengan serius , sering berpendapat dan merespon apa yang diungkapkan temannya, mendengarkan dengan baik dan tidak memotong pembicaraan teman,siswa mengungkapkan ide atau gagasannya tanpa harus ditunjuk, saling berinteraksi antar teman dalam kelompok dengan baik tanpa adanya permusuhan.

Pada siklus II pemberian layanan dirasa sudah cukup karena sudah ada peningkatan manajemen konflik pada diri siswa. Siswa sudah berani dalam mengungkapkan masalah, aktif menungkapakan 


\section{KHASANAH}

pendapat, bisa berinteraksi, dan bekerjasama dengan baik, saling menghormati dan menghargai pendapat orang lain sehingga siswa sudah bisa memahamipentingnya manajemen konflik. Setelah melihat hasil obsevasi yang dicapai setiap siswa dalam setiap siklus tindakan, maka terdapat peningkatan manajemen konflik. Dengan demikian hipotesis yang diajukan dalam penelitian ini teruji kebenarannya. Hal ini menunjukkan bahwa manajemen konflik dapat ditingkatkan melalui layanan konseling kelompok.

\section{Simpulan}

Ada peningkatan manajemen konflik melalui layanan konseling kelompok pada siswa kelas XI KAYU A SMK N 5 Yogyakarta tahun ajaran 2014/2015 dengan melihat perbedaan yang signifikan dilihat dari mean sebelum dilakukan konseling kelompok 111.62 (kategori sedang) Sedangkan setelah dilakukan konseling kelompok berada pada kategori tinggi dengan jumlah frekuensi 4 sebesar $50 \%$ dan kategori sangat tinggi dengan frekuensi 4 sebesar 50\%. Dengan demikian konseling kelompok yang digunakan dapat efektif meningkatkan kemampuan manajemen konflik.

Disarankan bagi para guru bimbingan dan konseling untuk dapat meningkatkan kemampuan managemen konflik pada siswa, yang dapat dilakukan dengan pemberian layanan konseling kelompok. Guru bimbingan dan konseling diharapkan mampu memberikan layanan konseling kelompok yang sesuai dengan kebutuhan siswa, dengan waktu yang tepat, tempat yang nyaman, dan dilakukan secara berkelanjutan. Informasi dari hasil penelitian ini bagi guru BK dapat dijadikan sebagai dasar pengembangan layanan konseling kelompok untuk membantu meningkatkan kemampuan manajemen konflik dalam diri masing-masing siswa. Hasil penelitian ini juga dapat berguna bagi orangtua, kepala sekolah, Waka kesiswaan, wali kelas, dan guru mata pelajaran sebagai informasi dalam upaya meningkatkan kemampuan manajemen konflik siswa.

\section{Referensi}

Ali \& Asrori. 2009. Psikologi Remaja Pengembangan Peserta Didik. Edisi 6. Jakarta : PT. Bumi Aksara.

Aryanto. (1992). (Online), (http:// www.PerselisihanAntarRemaja_Ujianblogefa' s.html diperoleh tanggal 11 Maret 2014).

Hendricks, W. (2006). Bagaimana Mengelola Konflik. Jakarta: Bumi Aksara.

http://news.detik.com/berita/2034457/-ratusansiswa-sma-6-antarkan-jenazah-alawy-keliang-lahat edisi Selasa, 25 September 2012.

Mulyasa. (2012). Manajemen Pendidikan Karakter. Jakarta: Bima Aksara

Natawidjaja, Rochman. (2009), Konseling Kelompok, Konsep Dasar dan Pendekatan. Bandung: Rizqi.

Permendiknas Nomor 22 Tahun 2006 Tentang Standar Isi

Pruitt, Dean G. dan Jeffrey Z. Rubin. (2009). Teori Konflik Sosial (Cetakan II). Yogyakarta: Pustaka Pelajar.

Wahyudi. 2011. Manajemen Konflik dalam Organisasi. Bandung: Alfabeta.

Widaryati, Sri. (2013). Efektivitas Pengaruh Konseling Kelompok Terhadap Efikasi Diri Siswa SMA Negeri 1 Pengasih. PSIKOPEDAGOGIA Jurnal Bimbingan Konseling, 2(2): 25-31.

Winkel, W. S., Hastuti, S. (2006). Bimbingan dan Konseling di Institusi Pendidikan (Edisi Revisi, Cetakan Kelima). Yogyakarta: Universitas Sanatha Dharma.

Wirawan. (2013). Konflik dan Manajemen Konflik (Konflik Perubahan dan Pengembangan). Bandung: Mandar Maju.

Yusuf L.N, Syamsu. (2009). Program Bimbingan dan Konseling di Sekolah. Bandung: Rizqi Press. 